\title{
PENERAPAN DARI MODEL MATEMATIKA \\ PENGENDALIAN PERSEDIAAN BARANG (INVENTORY MODEL) PADA SISTEM PRODUKSI DI PD. HANDI MEUBEL CIREBON
}

\author{
Herri Sulaiman', Wahyu Hartono ${ }^{2}$, Jajo Firman Raharjo ${ }^{3}$ \\ ${ }^{1,2,3}$ FKIP, Pendidikan Matematika Universitas Swadaya Gunung Jati Cirebon \\ email: hs_msc@yahoo.com
}

\begin{abstract}
ABSTRAK
Penelitian ini bertujuan untuk mengetahui model pengendalian persediaan atau dikenal dengan istilah Economic Order Quantity (jumlah pemesanan ekonomis) dan dapat diterapkan pada sistem produksi di PD Handi Meubel Cirebon. Pengendalian persediaan sangat penting diterapkan oleh suatu perusahaan karena dapat meminimalkan biaya persediaan. PD Handi Meubel telah melakukan perhitungan dengan rumus umum total biaya persediaan. Lebih lanjut, peneliti mencoba memberikan model perhitungan dengan model Economic Order Quantity (EOQ) yang dapat memberikan keputusan tentang jumlah pemesanan. Hasil pengendalian persediaan pada PD Handi Meubel belum ekonomis karena besar biaya pemesanan (annual ordering cost) dan biaya penyimpanan (annual holding cost) tidak relatif sama. Hal ini menyebabkan total persediaan tidak mampu mencapai nilai minimum. Penerapan model EOQ dapat memberikan solusi kepada PD Handi Meubel karena total persediaan dari perusahaan tersebut dapat mencapai nilai minimum. Ketentuan pemesanan diperoleh dari hasil perhitungan menggunakan persamaan model EOQ yang dikenal dengan istilah Wilson Formula. Tujuan jangka panjang dari penelitian ini bagi prodi pendidikan matematika yaitu sebagai desain bahan ajar pada materi atau pokok bahasan yang ada di dalam mata kuliah Kalkulus Diferensial yang berbasis pada model pengembangan bahan ajar tertentu sehingga diharapkan dapat membantu mahasiswa dalam memahami konsep-konsep esensial yang ada di dalam mata kuliah tersebut, sehingga kebutuhan belajar mahasiswa dapat terpenuhi dengan baik. Target luaran yang diharapkan terlaksana setelah penelitian ini dilakukan yaitu mempublikasikan hasil penelitian ini melalui publikasi ilmiah, prosiding, dan pengayaan bahan ajar. Dengan demikian diharapkan hasil penelitian ini dapat bermanfaat secara luas bagi perusahaan dan mahasiswa. Metode penelitian yang digunakan adalah metode observasi dengan sistem wawancara terhadap kepala produksi di PD Handi Meubel Cirebon.
\end{abstract}

Kata kunci: Pengendalian, Persediaan, EOQ 


\section{PENDAHULUAN}

Setiap perusahaan bertujuan untuk mendapatkan laba yang maksimum, serta adanya kontinuitas dan kelancaran dalam menjalankan usaha, baik perusahaan jasa ataupun perusahaan manufaktur akan selalu memerlukan persediaan. Tanpa adanya persediaan, pengusaha selalu dihadapkan pada resiko bahwa perusahaan pada suatu waktu tidak dapat memenuhi keinginan konsumen. Hal ini dilakukan agar suatu perusahaan mampu bertahan dan bersaing dalam kondisi sesulit apapun. Kemajuan atau keberhasilan suatu industri salah satunya dipengaruhi oleh pengendalian persediaan (inventory). Pengendalian persediaan diharapkan dapat meningkatkan keuntungan sehingga meminimumkan biaya-biaya yang ditimbulkan.

Masalah umum dalam model inventory bersumber dari kejadian yang dihadapi setiap saat dalam bidang usaha, baik dibidang dagang maupun industri. Kejadian-kejadian tersebut dapat terjadi pada persediaan barang yang terlalu banyak atau mungkin persediaan barang terlalu sedikit untuk memenuhi permintaan konsumen di masa mendatang. Jika barang terlalu banyak dalam inventory, maka perusahaan harus menanggung biaya tambahan seperti ongkos pergudangan, jika barang terlalu sedikit maka menimbulkan kekurangan persediaan barang yang akhirnya akan merugikan perusahaan sendiri. Inventory berkaitan dengan penyimpanan persediaan barang yang cukup sehingga akan memastikan lancarnya sistem produksi atau kegiatan bisnis. Inventory meliputi bahan mentah atau bahan baku, bahan pembantu dalam proses work in place, suku cadang dan barang jadi (finished good). Manajemen inventory menentukan jumlah persediaan yang optimal dengan meminimumkan biaya total. Biaya total dalam inventory meliputi biaya pemesanan, biaya penyimpanan dan jumlah persediaan pertahun. Alasan perlunya manajemen inventory yaitu agar perusahaan dapat memenuhi pesanan pelanggan dalam waktu relatif singkat. Inventory dilakukan untuk menekan harga pokok perunit barang.
Berdasarkan latar belakang masalah yang telah diuraikan di atas, maka rumusan masalah dalam penelitian ini yaitu: 1) apakah model pengendalian persediaan (inventory) yang telah dilakukan dalam PD. Handi Meubel sudah ekonomis? 2) apakah model pengendalian persediaan (inventory) sesuai dengan masalah real mengenai pengendalian persediaan bahan baku di PD. Handi Meubel? 3) bagaimana penerapan model inventory deterministik dengan adanya kebutuhan tetap dalam pengendalian bahan baku produksi di perusahaan furnitur yang memproduksi kursi pada PD Handi Meubel?

Pada penelitian ini, dibatasi masalah pada konsep matematis yang melandasi pembentukan model inventory yaitu: 1) model inventory yang akan dibahas dibatasi pada bentuk model inventory deterministik yaitu model inventory dengan permintaan bersifat deterministik artinya permintaan yang diketahui secara pasti atau konstan terhadap waktu, 2) model inventory determinstik yang dibahas adalah model Economic Order Quantity (EOQ) dengan adanya kebutuhan tetap, 3) produk yang akan dihitung pada penelitian ini adalah bahan baku kayu jati untuk produksi kursi.

Berdasarkan masalah penelitian yang telah dirumuskan di atas, maka penelitian ini bertujuan untuk: $\quad 1$ ) mengetahui keekonomisan dari model pengendalian persediaan (inventory) pada sistem produksi yang telah berjalan di PD. Handi Meubel, 2) mengetahui kesesuaian dari model pengendalian persediaan (inventory) terhadap masalah real mengenai pengendalian persediaan bahan baku di PD. Handi Meubel, 3) mengetahui penerapan dari model inventory deterministik dengan adanya kebutuhan tetap pada pengendalian bahan baku kayu di perusahaan furnitur yang memproduksi kursi.

Manfaat dari penelitian ini adalah 1) diharapkan dengan hasil penelitian ini dapat memperkaya wawasan ilmu pengetahuan tentang pengendalian persediaan barang yaitu dengan model Economic Order Quantity (EOQ) yang diaplikasikan di perusahaan furnitur PD. Handi Meubel Cirebon. 2) dapat 
digunakan sebagai media informasi sekaligus acuan bagi peneliti untuk mengembangkan kajian riset dalam hal penerapan matematika di bidang ekonomi khususnya untuk bidang ilmu manajemen dalam hal pengendalian persediaan barang. 3) memberikan gambaran umum dan pengetahuan bagi perusahaan mengenai penerapan dari model inventory deterministik.

\section{PENGERTIAN PENGENDALIAN}

Pengendalian adalah suatu fungsi manajemen yang bertujuan untuk mengusahakan agar aktivitas dapat berjalan selaras dengan perencanaan dan mengarah pada sasaran yang ditetapkan. Suatu perusahaan perlu melakukan pengendalian untuk menghindari penyimpanan dari rencana dan tujuan yang akan menimbulkan penghamburan sumber daya yang pada gilirannya sedikit demi sedikit akan mengikis kemampuan finansial perusahaan.

Menurut Bambang. R, 1979, pengendalian intern (internal control) mempunyai dua fungsi utama yaitu: mengamankan sumber daya harta perusahaan dari penyalahgunaan, $\quad 2$ ) mendorong efisiensi operasi perusahaan sehingga kebijaksanaan ataupun tujuan manajemen yang telah digariskan dapat tercapai.

Pengendalian yang diarahkan kepada pengamanan harta dari penyalahgunaan disebut pengendalian preventif. Pengendalian ini ditetapkan untuk mencegah inefisiensi sedangkan pengendalian yang khususnya untuk mendorong efisiensi operasi dan baru dilaksanakan setelah pengendalian preventif berakhir disebut pengendalian administrasi. Adapun 4 unsur pokok dalam pengendalian intern adalah sebagai berikut: 1) struktur perusahaan yang memisahkan tanggung jawab fungsional secara tegas, 2) sistem wewenang dan prosedur pencatatan yang memberikan perlindungan yang cukup terhadap kekayaan, hutang, pendapatan dan biaya, 3) praktik yang sehat dalam melaksanakan tugas dan fungsi setiap unit organisasi, 4) karyawan yang mutunya sesuai dengan tanggung jawabnya. Perusahaan akan beroperasi dengan efektif dan efisien, jika manajemen perusahaan melakukan pengendalian (control) terhadap setiap aktivitas yang ada di perusahaan. Dengan melakukan pengendalian yang baik dan pelaksanaan yang penuh disiplin, diharapkan pemborosan-pemborosan yang tidak perlu dapat dihindarkan dan perusahaan dapat beroperasi dengan lebih efisien dimasa yang akan datang. Hal ini merupakan faktor yang sangat penting untuk mendorong tercapainya tujuan perusahaan yaitu memperoleh laba yang maksimal.

\section{LINGKUNGAN PENGENDALIAN}

Lingkungan pengendalian mencerminkan sikap dan tindakan para pemilik dan manajer perusahaan mengenai pentingnya pengendalian intern perusahaan. Efektivitas unsur pengendalian intern sangat ditentukan oleh atmosfer yang diciptakan oleh lingkungan pengendalian. Lingkungan pengendalian ini harus diberi tekanan perhatian, karena berdasarkan kenyataan justru lingkungan pengendalian ini mempunyai dampak besar terhadap keseriusan pengendalian intern yang diterapkan di dalam perusahaan (Bambang.R, 1979).

\section{PENGERTIAN PERSEDIAAN}

Setiap perusahaan, apakah perusahaan itu perusahaan jasa ataupun perusahaan manufaktur selalu memerlukan persediaan. Tanpa adanya persediaan, para pengusaha akan dihadapkan pada resiko bahwa perusahaannya pada suatu waktu tidak dapat memenuhi keinginan konsumennya (Freedy Rangkuty : 2005).

Hal ini mungkin saja terjadi, karena tidak selamanya barang-barang atau jasa tersedia pada setiap saat, yang berarti bahwa pengusaha akan kehilangan kesempatan untuk memperoleh keuntungan yang seharusnya didapatkan. Jadi, persediaan sangat penting untuk setiap perusahaan baik yang menghasilkan suatu barang maupun jasa. Persediaan ini diadakan apabila keuntungan yang diharapkan dari persediaan tersebut terjamin kelancarannya, dengan demikian perlu diusahakan keuntungan yang diperoleh lebih besar dari biaya-biaya yang ditimbulkan. Pengertian mengenai persediaan adalah sebagai suatu aktiva yang meliputi barang- 
barang milik perusahaan denga maksud untuk dijual dalam suatu periode usaha tertentu atau persediaan barang-barnag yang masih dalam pengerjaan/proses produksi, ataupun persediaan bahan baku yang yang menunggu pengunannya dalam suatu proses produksi. Jadi, persediaan merupakan sejumlah bagianbagian yang disediakan serta bahan-bahan dalam proses produksi atau barang-barang jadi/produk yang disediakan untuk memenuhi permintaan dari konsumen atau langganan setiap waktu.

Persediaan atau inventory adalah riset operasi yang mempunyai maksud dan makna persediaan barang. Inventori adalah suatu barang yang disimpan dan menunggu untuk digunakan. Inventori dalam produksi adalah persediaan akan bahan-bahan yang dibutuhkan dalam proses produksi. Kontrol inventori adalah kegiatan dan teknik pemeliharaan kesediaan barang pada tingkat yang diinginkan apakah bahan baku, barang setengah jadi (bahan dalam proses) atau barang jadi (finished good) (Schmidt, dkk: 1993).

Persediaan (inventory) adalah sumber daya ekonomi fisik yang perlu diadakan dan dipelihara untuk menunjang kelancaran produksi meliputi bahan baku (raw material), produk jadi (finish product), komponen rakitan (component), bahan pembantu (substance material) dan bahan dalam proses pengerjaan (Haning Murdifin, dkk: 2007).

Pada prinsipnya persediaan mempermudah atau memperlancar jalannya operasi perusahaan pabrik yang harus dilakukan secara berturut-turut untuk memproduksi barang-barang serta selanjutnya menaympaikannya kepada para langganan atau konsumen. Persediaan memungkinkan produk-produk dihasilkan pada tempat yang jauh dari langganan atau sumber bahan mentah, dengan adanya persediaan, produksi tidak perlu dilakukan khusus buat konsumen atau sebaliknya tidak perlu konsumsi didesak agar sesuai dengan kepentingan produksi.

\section{MODEL MATEMATIKA} PENGENDALIAN PERSEDIAAN

Dalam persoalan persediaan dikenal beberapa model (inventory model). Masingmasing model mempunyai karakteristik tersendiri sesuai dengan parameter persoalan. Pada dasarnya model persediaan dibagi menjadi dua kelompok utama yaitu model deterministik dan model stokastik. Model deterministik semua parameter-parameternya yang berupa nilai-nilai acak diasumsikan dan diketahui dengan pasti.

Dalam model persoalan persediaan ini akan dicari berapa jumlah pemesanan (Q) sehingga total annual cost mencapai minimum.

Berikut ini diberikan gambar dari frekuensi pemesanan.

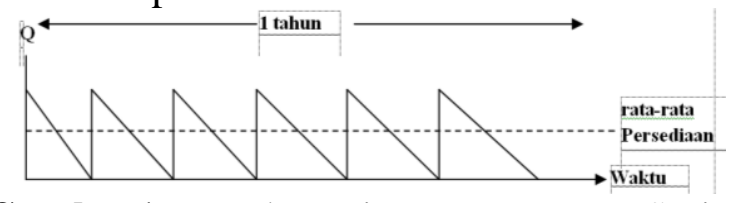

Gambar1. Frekuensi Pemesanan Sering Dilakukan

Berdasarkan Gambar 1 dapat dijelaskan bahwa Q merupakan jumlah barang yang dipesan secara periodik. Order point adalah saat dimana siklus persediaan (inventory cycle) yang baru dimulai dan yang lama berakhir. Setiap siklus persediaan mempunyai periode $\mathrm{T}$, artinya setiap $\mathrm{T}$ satuan waktu pemesanan kembali dilakukan dan ini tergantung pada $\mathrm{Q}$. Lamanya $\mathrm{T}$ sama dengan proporsi kebutuhan selama satu periode (A).

Dengan demikian:

$$
T=\frac{Q}{A}
$$

Mengetahui jumlah persediaan dari waktu ke waktu dapat digunakan gradien A sebagai petunjuk dengan cara melihat garis lurus yang memiliki gradient tersebut. Karena barang yang dipesan diasumsikan segera tersedia maka setiap siklus persediaan dapat dilukiskan dalam bentuk segitiga dengan tinggi $Q$ dan alas T. Frekuensi pemesanan tergantung pada $\mathrm{A}$ dan $\mathrm{Q}$ yang dirumuskan oleh frekuensi pemesanan $=\frac{A}{Q}$. 
Berikut ini diberikan gambar dari jumlah persediaan dengan tingkat pemakaian terhadap periode waktu.

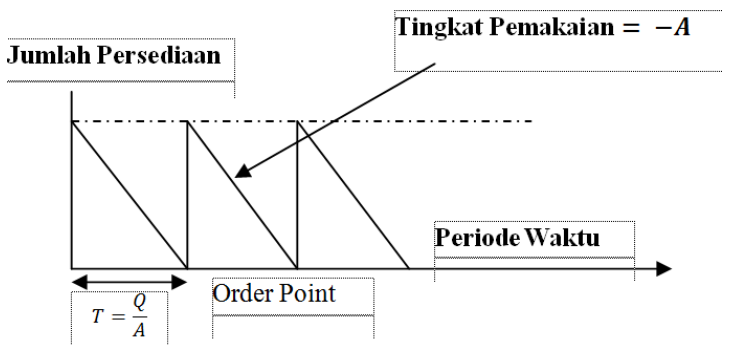

Gambar 2. Jumlah Persediaan Dengan Tingkat Pemakaian Terhadap Periode Waktu.

Jika frekuensi pemesanan dikali dengan biaya setiap pemesanan $(k)$ maka akan diperoleh:

$$
\text { Annual ordering cost }=\left(\frac{\mathrm{A}}{\mathrm{Q}}\right) \mathrm{k}
$$

Komponen biaya kedua adalah holding cost, yang ditentukan oleh jumlah dan lamanya barang disimpan. Setiap waktu jumlah barang berkurang sehingga perlu diperhatikan tingkat persediaan rata-rata, karena persediaan bergerak dari Q unit sampel nol unit sampel dengan tingkat pengurangan yang konstan $(-A)$ maka persediaan rata-rata untuk setiap siklus dapat dihitung dengan rumus:

$$
\text { Rata }- \text { rata persediaan }=\frac{\mathrm{Q}}{2}
$$

Holding cost dihitung berdasarkan satuan nilai persediaan dan procurement cost (c) sehingga: sehingga:

\section{Holding cost perunit barang $=h c$}

Annual holding cost $=\mathrm{hc}\left(\frac{\mathrm{Q}}{2}\right)$

Dalam satu periode (tahun) dibutuhkan A unit barang untuk pengadaan (procurement) dan biaya pengadaan sebesar $c$ setiap unit barang sehingga:

\section{Annual procurement cost $=\mathrm{Ac}$}

Jika ketiga komponen biaya tersebut di aats digabungkan maka akan didapat:

$$
\text { total annual cost }=\left(\frac{\mathrm{A}}{\mathrm{Q}}\right) \mathrm{k}+\mathrm{hc}\left(\frac{\mathrm{Q}}{2}\right)+\mathrm{Ac}
$$

Seperti sudah dijelaskan di awal bahwa tujuan dari model persoalan persediaan adalah meminimumkan total annual cost (TC). Total annual cost minimum dapat dicari dengan menentukan berapa jumlah pemesanan (Q). Karena yang mengandung Q pada fungsi total annual cost hanya ada pada annual ordering cost dan annual holding cost maka akan lebih sederhana jika $A c$ diabaikan dalam perhitungan. Total annual cost mencapai minimum jika antara fungsi annual ordering cost dan total annual holding cost berharga sama. Perhitungan ekonomisnya dapat ditulis sebagai berikut:

$$
\begin{aligned}
& h c\left(\frac{Q}{2}\right)=\left(\frac{A}{Q}\right) k \\
& \Leftrightarrow Q^{2}=\frac{2 A k}{h c} \\
& \Leftrightarrow Q^{*}=\sqrt{\frac{2 A k}{h c}}
\end{aligned}
$$

Berikut ini diberikan gambar mengenai kurva komponen biaya persediaan.

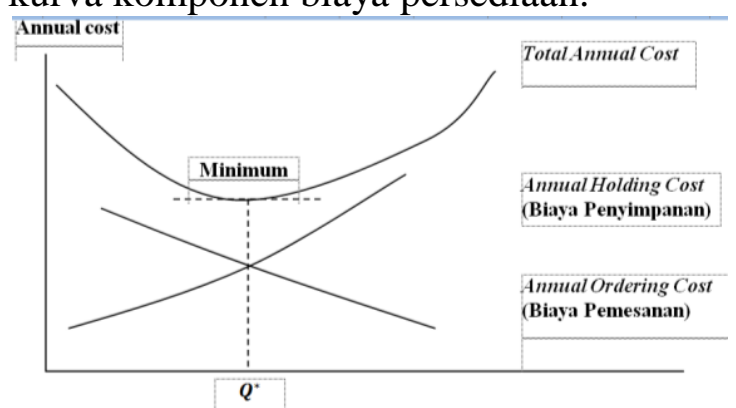

Gambar 3. Kurva komponen-komponen biaya persediaan

\section{METODE PENELITIAN}

Jenis penelitian yang digunakan dalam penelitian ini adalah penelitian studi lapangan (field study) yaitu penelitian yang dilakukan dengan mencari data melalui survei lapangan untuk mendapatkan data yang berkaitan dengan topik/masalah yang dibahas.

Objek pada penelitian ini adalah perusahaan daerah yang berada di desa Sutawinangun, Cirebon yaitu PD Handi Meubel khususnya divisi produksi. Penelitian ini dilaksanakan mulai bulan Juni 2016 sampai dengan Agustus 2016 di PD Handi Meubel. Meliputi data-data persediaan bahan baku, profil perusahaan PD Handi Meubel, data gaji 
karyawan, biaya gudang dan lain sebagianya yang berhubungan dengan penelitian ini.

Data yang diperoleh dalam penelitian ini pada dasarnya merupakan data primer yang berasal dari hasil wawancara oleh pengelola PD Handi Meubel. Data yang diperlukan dalam penelitian ini adalah data yang mendukung dalam penerapan model inventori deterministik dengan adanya kebutuhan tetap dalam pengendalian bahan baku produksi kursi furnitur.

Metode pengambilan data dalam penelitian ini diperoleh dengan cara:1) metode wawancara (interview), pengumpulan data dengan cara tanya jawab dengan pihak perusahaan PD Handi Meubel yang diperlukan untuk memperoleh data, 2) metode observasi, pengumpulan data dengan cara mengadakan pencatatan secara langsung kepada PD Handi Meubel tentang objek penelitian. 3) study literature, pengumpulan data dari berbagai literatur baik tentang landasan teori maupun informasi pendukung tentang penentuan jumlah tenaga kerja optimal dari data perusahaan.

Metode yang digunakan adalah model pengendalian persediaan (inventory model) yang telah dilakukan oleh perusahaan. Data yang diperoleh dianalisis dengan rumus umum pengendalian persediaan. Kemudian dari perhitungan akan diketahui bahwa pengendalian persediaan bahan baku pada perusahaan sudah ekonomis atau belum. Apabila perusahaan diketahui belum ekonomis, maka dari data yang ada penulis akan menerapkan model pengendalian persediaan bahan baku yang sesuai dengan karakteristik data. Karena data-data sangat penting untuk menentukan sebuah model. Dari penerapan model diharapkan dapat memperoleh total biaya persediaan yang minimum.

\section{HASIL PENELITIAN}

Perusahaan PD. Handi Meubel yang bergerak dibidang pembuatan furniture, beralamatkan di Jl. Pecilon Indah, Desa Sutawinangun Cirebon. Ketersediaan PD.
Handi Meubel dalam hal bahan baku sudah tidak menjadi masalah karena bahan baku selalu tersedia dengan baik apabila ada permintaan maka dapat segera terpenuhi.

PD. Handi Meubel mendapat kiriman bahan baku kayu yang dikirim dua kali setiap bulannya dari pemasok. Hubungan perusahaan dengan pemasok terjalin dengan baik, karena terdapat hubungan yang saling menguntungkan. PD. Handi Meubel juga melakukan pemilihan pada bahan baku pada saat datang. Hal ini meliputi kualitas kayu, ukuran diameter kayu dan jenis kayu yang dipesan yaitu kayu jati.

PD.Handi Meubel memesan bahan baku yang digunakan dan menyimpannya. Bahan baku yang disimpan sejenis (homogen) yaitu kayu jati permintaan per periode diketahui dan konstan. Ordering cost (pemesanan) konstan, holding cost (penyimpanan) pada penelitian ini berdasarkan rata-rata pesediaan, harga per unit produk konstan dan barang yang dipesan segera tersedia (tidak diijinkan back order).

Data penelitian di atas dengan asumsiasumsi yang telah dipakai maka model pengendalian persediaan menggunakan model EOQ (Economic Order Quantity) klasik. Pada saat kiriman kayu jati datang ke PD. Handi Meubel sudah sesuai dengan kesepakatan jumlah pesanan, perusahaan tidak mengeluarkan untuk biaya transportasi karena masih berada di dalam kota Cirebon. Saat ada bahan baku datang perusahaan masih menggunakan tenaga manusia untuk aktivitas bongkar muatan. Hal ini dilakukan dengan tujuan pengamatan pemilihan kayu secara teliti.

PD.Handi Meubel melakukan perhitungan pengendalian persediaan berdasarkan proses atau kebiasaan dari perusahaan itu sendiri. Hasil penelitian berikut ini akan diuraikan tentang data-data yang berasal dari perusahaan meliputi data permintaan produk kursi pada tahun 2015, jumlah tenaga kerja dan jam kerja karyawan, biaya inventory dan data produksi. 
DATA PERMINTAAN TAHUN 2015

Penelitian pada PD. Handi Meubel dalam memproduksi kursi menggunakan bahan kayu jati. Data permintaan produk kursi dari bulan Januari 2015 sampai dengan bulan Desember 2015 dapat dilihat pada Tabel 1.
Berdasarkan data pada Tabel 1 dapat diketahui bahwa permintaan setiap bulan diketahui dengan pasti yaitu jumlah pemesanan sama setiap bulannya yaitu 1200 unit. Total permintaan kursi dari bulan Januari 2015 sampai dengan bulan Desember 2015 berjumlah 14400 unit.

Tabel 1

Permintaan Produk Kursi Tahun 2015

\begin{tabular}{llcc}
\hline No. & \multicolumn{1}{c}{ Bulan } & Tahun & Kursi \\
\hline 1 & Januari & 2015 & 1200 \\
\hline 2 & Februari & 2015 & 1200 \\
\hline 3 & Maret & 2015 & 1200 \\
\hline 4 & April & 2015 & 1200 \\
\hline 5 & Mei & 2015 & 1200 \\
\hline 6 & Juni & 2015 & 1200 \\
\hline 7 & Juli & 2015 & 1200 \\
\hline 8 & Agustus & 2015 & 1200 \\
\hline 9 & September & 2015 & 1200 \\
\hline 10 & Oktober & 2015 & 1200 \\
\hline 11 & November & 2015 & 1200 \\
\hline 12 & Desember & 2015 & 1200 \\
\hline & & Total & $\mathbf{1 4 4 0 0}$ \\
\hline
\end{tabular}

Sumber: Data Sekunder PD. Handi Meubel Tahun 2015

\section{BIAYA INVENTORY}

Biaya penyimpanan adalah biaya yang dikeluarkan untuk menyimpan kayu jati di gudang. Biaya tersebut terdiri dari biaya gudang, gaji pegawai dan biaya fasilitas, adapun besar biaya penyimpanan untuk produk dapat disajikan melalu tabel di bawah ini.

Tabel 2

Biaya Simpan Bahan Baku Kayu Jati pada Tahun 2015

\begin{tabular}{llcccccc}
\hline No. & Bulan & Tahun & $\begin{array}{c}\text { Biaya } \\
\text { Gudang } \\
(\mathbf{R p .})\end{array}$ & $\begin{array}{c}\text { Gaji } \\
\text { Pegawai } \\
\text { Gudang } \\
(\mathbf{R p .})\end{array}$ & $\begin{array}{c}\text { Biaya } \\
\text { Fasilitas } \\
(\mathbf{R p .})\end{array}$ & $\begin{array}{c}\text { Total } \\
\text { Biaya } \\
(\mathbf{R p .})\end{array}$ & $\begin{array}{c}\text { Kayu } \\
\text { dang } \\
\text { disimpan } \\
\left(\mathbf{m}^{\mathbf{3}}\right)\end{array}$ \\
\hline 1 & Januari & 2015 & 300.000 & 500.000 & 25.000 & 825.000 & 1125,3 \\
\hline 2 & Februari & 2015 & 300.000 & 500.000 & 25.000 & 825.000 & 1125,3 \\
\hline 3 & Maret & 2015 & 300.000 & 500.000 & 25.000 & 825.000 & 1125,3 \\
\hline 4 & April & 2015 & 300.000 & 500.000 & 25.000 & 825.000 & 1125,3 \\
\hline 5 & Mei & 2015 & 300.000 & 500.000 & 25.000 & 825.000 & 1125,3 \\
\hline 6 & Juni & 2015 & 300.000 & 500.000 & 25.000 & 825.000 & 1125,3 \\
\hline 7 & Juli & 2015 & 300.000 & 500.000 & 25.000 & 825.000 & 1125,3 \\
\hline 8 & Agustus & 2015 & 300.000 & 500.000 & 25.000 & 825.000 & 1125,3 \\
\hline 9 & September & 2015 & 300.000 & 500.000 & 25.000 & 825.000 & 1125,3 \\
\hline 10 & Oktober & 2015 & 300.000 & 500.000 & 25.000 & 825.000 & 1125,3
\end{tabular}




\begin{tabular}{llcccccc}
\hline No. & Bulan & Tahun & $\begin{array}{c}\text { Biaya } \\
\text { Gudang } \\
(\mathbf{R p .})\end{array}$ & $\begin{array}{c}\text { Gaji } \\
\text { Pegawai } \\
\text { Gudang } \\
(\text { Rp. })\end{array}$ & $\begin{array}{c}\text { Biaya } \\
\text { Fasilitas } \\
(\text { Rp. })\end{array}$ & $\begin{array}{c}\text { Total } \\
\text { Biaya } \\
(\text { Rp. })\end{array}$ & $\begin{array}{c}\text { Kayu } \\
\text { yang } \\
\text { disimpan } \\
\left(\mathbf{m}^{\mathbf{3}}\right)\end{array}$ \\
\hline 11 & November & 2015 & 300.000 & 500.000 & 25.000 & 825.000 & 1125,3 \\
\hline 12 & Desember & 2015 & 300.000 & 500.000 & 25.000 & 825.000 & 1125,3 \\
\hline & Total & & $\mathbf{3 . 6 0 0 . 0 0 0}$ & $\mathbf{6 . 0 0 0 . 0 0 0}$ & $\mathbf{3 0 0 . 0 0 0}$ & $\mathbf{9 . 9 0 0 . 0 0 0}$ & $\mathbf{1 3 5 0 3 , 6}$ \\
\hline & Rata-rata & & & & & & $\mathbf{1 1 2 5 , 3}$ \\
\hline
\end{tabular}

Sumber: Data Sekunder PD. Handi Meubel Tahun 2015

Berdasarkan data pada Tabel 2 di atas dapat dilihat bahwa jumlah pegawai gudang untuk produksi kursi adalah satu orang dengan gaji perbulan Rp.500.000,-, biaya gudang sebesar Rp.300.000,-, dan biaya fasilitas sebesar Rp.25.000,-.

\section{DATA BIAYA PRODUKSI}

PD. Handi Meubel merupakan salah satu perusahaan yang memproduksi meubel berbahan baku kayu jati, beberapa produknya adalah almari, meja, kursi, tempat tidur, dan rak buku. Perusahaan ini memproduksi sesuai dengan pesanan (job order) dalam hal ini permintaan terhadap produk kursi telah diketahui tetap dalam setahun. Perhitungan kebijakan optimum yang dilakukan secara manual membutuhkan waktu yang cukup lama dan tingkat ketelitiannya kurang. Maka dari itu seiring dengan perkembangan IPTEK untuk perhitungan dengan kebijakan optimum model inventory dapat dilakukan dengan berbantuan softwere komputer yaitu Microsoft Office Excell.

\section{MODEL PENGAWASAN PERSEDIAAN DENGAN ADANYA KEBUTUHAN TETAP}

Pengawasan persediaan merupakan salah satu fungsi manajemen yang dapat dipecahkan dengan menerapkan model kuantitatif. Konsep ini dapat diterapkan baik untuk industri skala kecil maupun skala besar. Analisis data secara kuantitatif dapat dipilih secara tepat, sekalipun di dalam perusahaan yang telah dikelola dengan baik. Model ini dapat dilaksanakan apabila kebutuhan-kebutuhan permintaan di masa yang akan datang memiliki jumlah yang konstan dan relatif memiliki fluktuasi perubahan yang sangat kecil. Apabila jumlah permintaan telah diketahui, maka dapat diasumsikan bahwa jumlah permintaan dan masa tenggang merupakan bilangan yang konstan dan diketahui.

\section{BIAYA BAHAN BAKU UTAMA}

Perusahaan dalam membuat produk kursi tidak lepas dari pembelian bahan baku utama kayu jati. Perusahaan membeli bahan baku kayu jati sebanyak $45 \mathrm{~m}^{3} /$ bulan dengan harga Rp.6.500.000,-/ $/ \mathrm{m}^{3}$ dapat menghasilkan 1200 unit kursi. Dengan demikian untuk:

Harga kayu $45 \mathrm{~m}^{3} \times$ Rp.6.500.000,- = Rp. 292.500.000,-. Sedangkan untuk harga kursi tiap satuannya yaitu:

$$
\begin{aligned}
\text { Harga Kursi } & =\frac{\text { Rp. } 292.500 .000}{1200} \\
& =\text { Rp. 243.750, }- \text { /unit } .
\end{aligned}
$$

\section{KAPASITAS GUDANG BAHAN BAKU \\ Luas gudang penyimpanan untuk} bahan baku kayu jati adalah $35 \mathrm{~m} \times 45 \mathrm{~m}$. Kapasitas penyimpanan maksimum yaitu $45 \mathrm{~m}^{3}$

\section{BIAYA PENGIRIMAN DAN PEMESANAN}

Perusahaan melakukan pengiriman pemesanan barang dengan frekuensi dua kali dalam satu bulan. Biaya pengiriman kayu jati per kirimnya adalah Rp.1.250.000,-. Sedangkan total biaya pengiriman dalam satu bulan adalah Rp.2.500.000,-. Untuk lebih jelasnya dapat dilihat pada tabel di bawah ini. 
Tabel 3

Biaya Simpan Bahan Baku Kayu Jati pada Tahun 2015

\begin{tabular}{llccccc}
\hline No. & Bulan & Tahun & Frekuensi & $\begin{array}{c}\text { Biaya per } \\
\text { kirim }(\mathbf{R p .})\end{array}$ & $\begin{array}{c}\text { Total Biaya } \\
(\mathbf{R p .})\end{array}$ & $\begin{array}{c}\text { Kayu yang } \\
\text { dipesan }\left(\mathbf{m}^{\mathbf{3}}\right)\end{array}$ \\
\hline 1 & Januari & 2015 & 2 & 1.250 .000 & 2.500 .000 & 2,875 \\
\hline 2 & Februari & 2015 & 2 & 1.250 .000 & 2.500 .000 & 2,875 \\
\hline 3 & Maret & 2015 & 2 & 1.250 .000 & 2.500 .000 & 2,875 \\
\hline 4 & April & 2015 & 2 & 1.250 .000 & 2.500 .000 & 2,875 \\
\hline 5 & Mei & 2015 & 2 & 1.250 .000 & 2.500 .000 & 2,875 \\
\hline 6 & Juni & 2015 & 2 & 1.250 .000 & 2.500 .000 & 2,875 \\
\hline 7 & Juli & 2015 & 2 & 1.250 .000 & 2.500 .000 & 2,875 \\
\hline 8 & Agustus & 2015 & 2 & 1.250 .000 & 2.500 .000 & 2,875 \\
\hline 9 & September & 2015 & 2 & 1.250 .000 & 2.500 .000 & 2,875 \\
\hline 10 & Oktober & 2015 & 2 & 1.250 .000 & 2.500 .000 & 2,875 \\
\hline 11 & November & 2015 & 2 & 1.250 .000 & 2.500 .000 & 2,875 \\
\hline 12 & Desember & 2015 & 2 & 1.250 .000 & 2.500 .000 & 2,875 \\
\hline & Total & & $\mathbf{2 4}$ & $\mathbf{1 5 . 0 0 0 . 0 0 0}$ & $\mathbf{3 0 . 0 0 0 . 0 0 0}$ & $\mathbf{3 4 , 5 0 0}$ \\
\hline & Rata-rata & & & & & $\mathbf{2 , 8 7 5}$ \\
\hline
\end{tabular}

Sumber: Data Sekunder PD. Handi Meubel Tahun 2015

Sedangkan untuk biaya pemesanan kayu jati tahun 2015 dapat dilihat pada tabel di bawah ini.

Tabel 4

Biaya Simpan Bahan Baku Kayu Jati pada Tahun 2015

\begin{tabular}{|c|c|c|c|c|c|c|c|}
\hline No. & Bulan & Tahun & $\begin{array}{c}\text { Pembelian } \\
\text { Kayu Jati } \\
\quad \text { (Rp.) }\end{array}$ & $\begin{array}{c}\text { Biaya } \\
\text { Bonkar } \\
\text { (Rp.) }\end{array}$ & $\begin{array}{c}\text { Biaya } \\
\text { Telepon } \\
\text { (Rp.) }\end{array}$ & $\begin{array}{l}\text { Biaya } \\
\text { lain } \\
\text { (Rp.) }\end{array}$ & $\begin{array}{c}\text { Total } \\
\text { Biaya } \\
\text { (Rp.) }\end{array}$ \\
\hline 1 & Januari & 2015 & 2.500 .000 & 225.000 & 150.000 & 50.000 & 2.925 .000 \\
\hline 2 & Februari & 2015 & 2.500 .000 & 225.000 & 150.000 & 50.000 & 2.925 .000 \\
\hline 3 & Maret & 2015 & 2.500 .000 & 225.000 & 150.000 & 50.000 & 2.925 .000 \\
\hline 4 & April & 2015 & 2.500 .000 & 225.000 & 150.000 & 50.000 & 2.925 .000 \\
\hline 5 & Mei & 2015 & 2.500 .000 & 225.000 & 150.000 & 50.000 & 2.925 .000 \\
\hline 6 & Juni & 2015 & 2.500 .000 & 225.000 & 150.000 & 50.000 & 2.925 .000 \\
\hline 7 & Juli & 2015 & 2.500 .000 & 225.000 & 150.000 & 50.000 & 2.925 .000 \\
\hline 8 & Agustus & 2015 & 2.500 .000 & 225.000 & 150.000 & 50.000 & 2.925 .000 \\
\hline 9 & September & 2015 & 2.500 .000 & 225.000 & 150.000 & 50.000 & 2.925 .000 \\
\hline 10 & Oktober & 2015 & 2.500 .000 & 225.000 & 150.000 & 50.000 & 2.925 .000 \\
\hline 11 & November & 2015 & 2.500 .000 & 225.000 & 150.000 & 50.000 & 2.925 .000 \\
\hline \multirow[t]{2}{*}{12} & Desember & 2015 & 2.500 .000 & 225.000 & 150.000 & 50.000 & 2.925 .000 \\
\hline & Total & & 30.000 .000 & 2.700 .000 & 1.800 .000 & 600.000 & 35.100 .000 \\
\hline
\end{tabular}

Sumber: Data Sekunder PD. Handi Meubel Tahun 2015 
Menurut tabel di atas, jumlah biaya telepon dan biaya lain termasuk variabel $\mathrm{k}$, merupakan biaya pemesanan (ordering cost). Jumlah biaya kirim dan biaya bongkar termasuk variabel c merupakan biaya pengadaan (procurement cost). Lebih lanjut berikut ini diberikan diagram untuk penerapan dari pemesanan kayu jati di PD. Handi Meubel pada tahun 2015 .

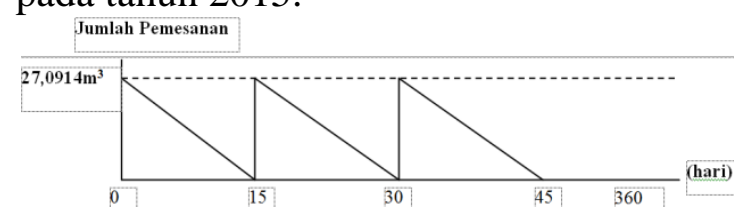

Gambar 4. Penerapan pemesanan kayu jati di PD.Handi Meubel pada tahun 2015

Dari gambar di atas dapat dijelaskan bahwa untuk hari pertama pemesanan kayu jati mencapai angka maksimum yaitu 27,091 m3. Kemudian untuk tiap kelipatan 15 hari bahan baku kayu jati tersebut diolah untuk pembuatan kursi sebanyak 1200 unit per bulan. Sehingga dari diagram di atas menunjukkan kemiringan garis yang berarti bahan baku berangsur habis hingga batas hari ke 15. Kemudian PD. Handi Meubel melakukan pemesanan kembali sebanyak $27,091 \mathrm{~m} 3$ dihari ke 16. Kegiatan seperti ini terus berlanjut hingga mendekati hari ke 365 atau selama satu tahun.

\section{BIAYA PENYIMPANAN (HOLDING COST/CARRYING COST)}

Perusahaan PD. Handi Meubel menyimpan persediaan sebagian besar mrupakan biaya penyimpanan fisik, pajak dan asuransi. Perusahaan PD. Handi Meubel dikenakan biaya pajak dan auransi masingmasing sebesar $5 \%$.

\section{DATA KAPASITAS JAM KERJA}

Kapasitas jam kerja di PD. Handi Meubel adalah sebagai berikut:

Hari kerja /bulan : 25 hari

Jam kerja/hari : 7 Jam (jam kerja untuk pegawai adalah 8 jam, namun diberlakukannya jam istirahat selama satu jam sehingga waktu efisiennya adalah 7 jam).

\section{PERHITUNGAN}

PD. Handi Meubel melakukan perhitungan pengendalian persediaan berdasarkan proses atau kebiasaan perusahaan untuk mencari jumlah bahan baku kayu jati setiap kali pemesanan. Komponen dalam perhitungannya meliputi data-data melalui beberapa tabel dan gambar yang telah dipaparkan di atas.

Menurut perhitungan perusahaan, maka peneliti terlebih dahulu menggolongkan variabel-variabel antara lain:

$\mathrm{k}=$ Biaya pemesanan (ordering cost) yaitu semua pengeluaran yang timbul untuk mendatangkan barang dari luar.

Variabel k diperoleh dari jumlah biaya telepon dan biaya lain-lain dibagi jumlah frekuensi pengiriman dalam sebulan. Data dapat dilihat pada Tabel 4. Sehingga perhitungan untuk nilai k yaitu:

$$
\begin{aligned}
\mathrm{k} & =\frac{\sum \text { biaya telepon dan biaya lain-lain }}{2} \\
& =\frac{\text { Rp.150.000,+Rp.50.000,- }}{2} \\
& =\frac{\text { Rp.200.000,- }}{2}=\text { Rp. } 100.000,-
\end{aligned}
$$

$A=$ Jumlah barang yang dibutuhkan dalam satu periode.

Jumlah bahan baku utama kayu jati yang dipesan dalam waktu satu tahun adalah 500 m3/tahun.

$\mathrm{c}=$ Procurement cost per unit barang yang dipesan yaitu sekelompok biaya pemesanan yang tergantung pada jumlah barang yang dipesan.

Total rincian biaya pemesanan per bulan periode tahun 2015 adalah:

$\mathrm{c}=\frac{\sum \text { Biaya pembelian kayu jati dan biaya bongkar }}{24}$,

$$
=\frac{\mathrm{Rp} \cdot 30.000 .000,-+\mathrm{Rp} \cdot 2.700 .000,-}{24} \text {, }
$$$$
=\text { Rp. } 1.362 .500,- \text {. }
$$

$\mathrm{h}=$ Holding cost per satuan nilai persediaan yaitu biaya yang timbul akibat disimpannya suatu item.

Dengan demikian diperoleh bahwa:

$\mathrm{h}=$ pajak dan asuransi

$\mathrm{h}=5 \%+5 \%=0,1 \%$

$\mathrm{T}=$ waktu antara pemesanan. 
Sehingga jumlah bahan baku setiap kali pemesanan adalah:

$\mathrm{Q}=$ total annual cost

$$
=\frac{500 \mathrm{~m}^{3} / \text { tahun }}{24}=20,833 \mathrm{~m}^{3} / 2 \text { minggu. }
$$

Dengan demikian dari perhitungan di atas dapat disimpulkan bahwa jumlah bahan baku setiap kali pemesanan yang dilakukan adalah $20,833 \mathrm{~m}^{3} / 2$ minggu.

\section{MODEL PENGENDALIAN PERSEDIAAN (INVENTORY MODEL) MENURUT RUMUS ECONOMIC ORDER QUANTITY (EOQ).}

Data-data yang dikumpulkan melalui metode interview, observasi dan studi literatur menyimpulkan bahwa model Economic Order Quantity (EOQ) dapat digunakan oleh PD. Handi Meubel dengan alasan: 1) barang yang dipesan dan disimpan hanya barang yang sejenis (homogen) yaitu kayu jati, 2) permintaan per periode diketahui dan konstan, 3) ordering cost konstan, 4) holding cost berdasarkan rata-rata persediaan, 5) Harga per unit barang konstan, 6) barang yang dipesan segera tersedia (tidak diijinkan back order).

Di dalam model EOQ (Economic Order Quantity) digunakan asumsi-asumsi untuk menyederhanakan sistem persediaan yang ada: 1) permintaan (kebutuhan) diketahui dengan pasti dan konstan sepanjang waktu, 2) pemesanan kembali dilakukan ketika persediaan mencapai titik nol, dan akan langsung diterima seketika sesuai ukuran pemesanan yang dilakukan sehingga tidak akan terjadi kekurangan persediaan.

Model EOQ (Economic Order Quantity) mencari ukuran pemesanan yang ekonomis dengan meminimalkan total biaya. Biaya penyimpanan pertahun merupakan perkalian antara rata-rata persediaan pertahun dengan biaya simpan per unit pertahun. Biaya pembelian pertahun (annual purchase cost) merupakan total harga yang dikeluarkan untuk membeli suatu barang, yaitu perkalian antara harga barang per unit dengan banyaknya barang yang dibeli sepanjang tahun. Sedangkan biaya pemesanan pertahun merupakan perkalian antara biaya per pesanan dikalikan dengan banyaknya pemesanan dalam satu tahun. Dengan demikian dari penjelasan di atas, maka rumus yang digunakan adalah sebagai berikut:

$$
\begin{aligned}
\mathrm{TC}= & {\left[\frac{\mathrm{A}}{\mathrm{Q}}\right] \mathrm{k}+\mathrm{hc} \frac{\mathrm{Q}}{2} } \\
= & {\left[\frac{500}{20,833}\right] 100.000+0,1 \times 1.362 .500 \times } \\
& \frac{20,833}{2}, \\
= & 2.400 .038+1.419 .248,125, \\
= & \text { Rp. 3.819.286,125/tahun }
\end{aligned}
$$

Pada model EOQ (Economic Order Quantity) telah dikenalkan model Formula Wilson. Model tersebut dapat menentukan jumlah pesanan yang ekonomis sehingga dapat meminimumkan total annual cost.

Cara Formula Wilson:

$$
\begin{aligned}
Q & =\sqrt{\frac{2 \mathrm{Ak}}{\mathrm{hc}}} \\
& =\sqrt{\frac{2 \times 500 \times 100.000}{0,1 \times 1.362 .500}} \\
& =\sqrt{733.944} \\
& =27,091 \mathrm{kayu} / \mathrm{m}^{3}
\end{aligned}
$$

Sedangkan untuk waktu optimal diberikan perhitungan sebagai berikut:

$$
\begin{aligned}
\mathrm{T}^{*} & =\frac{\mathrm{Q}^{*}}{\mathrm{~A}}, \\
& =\frac{27,091}{500}, \\
& =0,05 \text { tahun }=18,25 \text { hari }= \pm 2 \text { minggu }
\end{aligned}
$$

Jadi waktu optimal adalah dua minggu. Dengan $\mathrm{Q}^{*}$ disebut sebagai EOQ (Economic Order Quantity) sedangkan persamaannya disebut sebagai Formula Wilson. Selanjutnya untuk total minimum annual cost didapatkan perhitungan sebagai berikut:

$$
\begin{aligned}
\mathrm{TC}^{*}= & {\left[\frac{\mathrm{A}}{\mathrm{Q}^{*}}\right] \mathrm{k}+\mathrm{hc} \frac{\mathrm{Q}^{*}}{2} } \\
= & {\left[\frac{500}{27,091}\right] 100.000+0,1 \times } \\
& 1.362 .500 \times \frac{27,091}{2}, \\
= & 1.845 .631,39+1.845 .5748,375 \\
= & \text { Rp. 3.691.205,765/tahun }
\end{aligned}
$$

Terlihat dari hasil perhitungan bahwa total annual cost (Rp. 3.819.286,125/tahun) relatif sama dengan total annual cost optimum 
(Rp. 3.691.205,765/tahun) yang selama ini diterapkan oleh PD. Handi Meubel . Dengan tiap dua minggu sekali PD. Handi Meubel melakukan pemesanan, jumlah tiap kali pesan adalah 27,091 kayu/m3. Hasil perhitungan ini sesuai dengan syarat optimalisasi bahwa total annual cost harus relatif sama dengan annual cost optimum dan dapat disimpulkan bahwa perusahaan PD. Handi Meubel telah optimum dan ekonomis dalam pengendalian persediaan (Inventory Model) dengan adanya kebutuhan tetap untuk meminimalkan total biaya.

\section{MENYIMPULKAN HASIL PERHITUNGAN DAN APLIKASINYA}

Pengendalian persediaan merupakan salah satu fungsi manajerial yang sangat penting. Apabila perusahaan menanamkan terlalu banyak dananya dalam persediaan, hal ini akan menyebabkan biaya penyimpanan yang berlebihan dan mungkin mempunyai opportunity cost. Demikian pula apabila perusahaan tidak mempunyai persediaan yang mencukup, dapat mengakibatkan biaya-biaya dari terjadinya kekurangan bahan (stock cost).

PD. Handi Meubel menerapkan pengendalian persediaan untuk meminimumkan total biaya operasional perusahaan khususnya pada penyediaan bahan baku jati. Dalam menentukan jumlah yang dipesan pada setiap kali pemesanan, pada dasarnya harus memperhatikan dua hal yaitu melakukan pemesanan bahan baku kayu jati dalam jumlah yang sebesar-besarnya dan melakukan pemesanan bahan baku kayu jati dalam jumlah yang sekecil-kecilnya. Perlunya pengawasan pada persediaan adalah: 1) menjaga jangan sampai kehabisan persediaan, 2) agar pembentukan persediaan stabil, 3) menghindari pembelian kecilkecilan, 4) pemesanan yang ekonomis.

PD. Handi Meubel di dalam meminimalkan total biaya dapat menggunakan model EOQ (Economic Order Quantity) sesuai dengan hasil perhitungan yang telah dilakukan berdasarkan data-data yang dimiliki oleh perusahaan.

Total annual relevant cost atau jumlah setiap kali dalam melakukan pesanan harus diketahui terlebih dahulu variabel-variabel pendukungnya. Pada dasarnya total annual cost terdiri dari annual cost dan annual cost optimum. Kedua variabel tersebut harus seimbang, karena untuk mencapai hasil yang optimal. PD. Handi Meubel perlu menerapkan formula Wilson yaitu :

$$
\mathrm{Q}^{*}=\sqrt{\frac{2 \mathrm{Ak}}{\mathrm{hc}}}
$$

Penggunaan persamaan tersebut akan diperoleh hasil yang optimal dalam menentukan berapa dan kapan pemesanan harus dilakukan oleh PD. Handi Meubel dan total annual relevant cost dapat diminimumkan. Peneliti telah melakukan perhitungan sesuai yang telah dilakukan oleh PD. Handi Meubel. Kemudian menerapkan ke formula Wilson sebagai solusi yang ditawarkan, sehingga didapatkan hasil dari perhitungan yang dilakukan oleh PD. Handi Meubel adalah optimal (relatif sama).

Perhitungan yang dilakukan oleh PD. Handi Meubel didapatkan bahwa terlihat dari hasil perhitungan menunjukkan total annual cost sebesar (Rp. 3.819.286,125/tahun) relatif sama dengan total annual cost optimum (Rp. 3.691.205,765/tahun) yang selama ini diterapkan oleh PD. Handi Meubel dengan tiap dua minggu sekali PD. Handi Meubel melakukan pemesanan dengan jumlah tiap kali pesan yaitu ,091 kayu/m3. Dengan demikian PD. Handi Meubel dalam melakukan proses produksinya menjaga persediaan yang cukup agar kegiatan operasi produksinya dapat lancar dan efisien sehingga perusahaan dapat memenuhi jumlah permintaan dari konsumen dan untuk tahun kedepannya perusahaan dapat mempertahankan kinerja produksinya.

\section{SIMPULAN DAN SARAN}

Berdasarkan penjelasan yang telah dibahas pada hasil penelitian dapat disimpulkan bahwa: 1) total annual cost optimum relatif sama dengan total annual cost yang selama ini diterapkan oleh PD. Handi Meubel dengan pesanan tiap dua minggu sekali. Jadi, PD. Handi Meubel sudah optimal dalam pengendalian persediaan bahan baku kayu jati, 2) pengawasan persediaan 
merupakan salah satu fungsi manajemen yang dapat dipecahkan dengan menerapkan metode kuantitatif. Konsep ini dapat diterapkan baik untuk industri skala kecil maupun industri skala besar. Dengan demikian analisis secara kuantitatif, proses pengambilan keputusan dapat dipilih secara tepat, sekalipun di dalam perusahaan yang telah dikelola dengan baik.

Saran pada penelitian ini ditujukan kepada perusahaan PD. Handi Meubel dan bagi peneliti agar kedepannya riset mengenai model persediaan barang (inventory model) lebih dikembangkan lagi. 1) PD. Handi Meubel perlu mendokumentasi dengan baik data-data yang mendukung pengendalian persediaan, 2) PD. Handi Meubel perlu mencatat produk cacat yang harus diperbaiki dan mencatat bahan baku kayu jati secara teliti yang tidak sesuai dengan pesanan, 3) Perlu pengembangan lebih lanjut mengenai model persediaan barang seperti model inventory deterministic yang dapat diterapkan untuk kasus lain.

\section{DAFTAR RUJUKAN}

Dedi, Endang, Sumiaty,E., Juandi, D., Kusnandi, 2003. Kalkulus 1. Bandung: JICA-Universitas Pendidikan Indonesia.

Efendi, B., A., 2009. Pengendalian Persediaan Barang untuk Kebutuhan Permintaan pada PT. Marco Polo Decor (skripsi). Yogyakarta: UIN Sunan Kalijaga.

Supranto, Johanes, 2008. Riset Operasi (Untuk Pengambilan Keputusan). Jakarta: UI press M.Sayuti, Analisis Kelayakan Pabrik Yogyakarta: Graha Ilmu.

Kusumaningrum, R., D., 2009. Model Pengendalian Persediaan (Inventory Model) pada sistem produksi di CV. Putra Makmur Abadi (skripsi). Yogyakarta: UIN Sunan Kalijaga.

Rangkuti, Freddy, 2002. Manajemen Persediaan (Aplikasi di bidang bisnis), cet.5. Jakarta: PT. Grafindo Persada.
Riyanto, Bambang, 1979. Dasar-Dasar Pembelajaran Perusahaan. Yogyakarta: Yayasan Badan Penerbit Gadjah Mada.

Ginting, Rosnani, 2007. Sistem Produksi. Yogyakarta : Graha Ilmu.

Stewart, James, 2001. Kalkulus. Jakarta: Erlangga.

Prawirosentono, Suyadi, 2007. Manajemen Operasi. Jakarta: PT. Bumi Aksara.

Taha, H.A., 1996. Riset Operasi. Edisi Kelima, jilid 2, Jakarta: Binarupa Aksara.

Varbeg, D. dan Purcell, J., E., 2001. Kalkulus, Edisi Ketujuh, Jilid Satu. Batam: Interaksara.

Winston, Wayne L., 2004. Operations Research (Aplications and Algorithms). Fourth Edition, Indiana: Duxbury Press). 


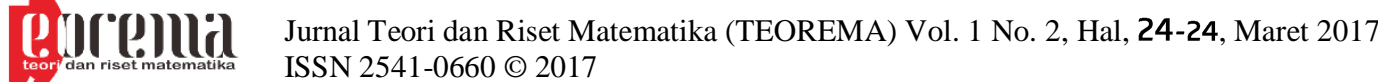

